\title{
Modernity and Domesticity in the French cité-jardins: The Case of the Cité de la Muette
}

\author{
ROBERT WEDDLE \\ University of Illinois at Urbana-Champaign \\ USA
}

In the first half of the 1930's, construction began on an illfated housing development to the northeast of Paris, called the Cite de la Muette. The design and construction of this development, as well as its eventual failure, marked an important turning-point in French conceptions of collective housing. Shortly after work was underway on the Cité, when descriptions of it began to appear in architectural journals, it became clear that this was to be a model for a distinctly new type of suburban community. The Cite, according to its promoters, would combine the most modern forms and materials, production techniques, and domestic conveniences to create attractive, inexpensive, and efficient housing.

Judged by these standards, however, the Cité was a disastrous failure. The first completed phase hit the rental market during the darkest days of the economic crisis, and it attracted few tenants. The public housing office which had commissioned the project eventually took it off the market altogether. The Cité was leased, in an unfinished state, to the French national police, who used it first as barracks, then as a prison. It was confiscated during the German occupation by the Gestapo and became the largest deportation camp in France. Between June 1942 and August 1944 some 67,000 Jews were sent from Drancy to Nazi death camps.' After the war the Cité once again housed French gendarmes, and it was partially demolished in the 1970's.

The inability of the Cité de la Muette to satisfy the various claims made for it by politicians, planners, and architects obscures the significant role it played in debates about cities and housing in inter-war France, and it is in relationship to those debates that it needs to be understood. The Cité was part of a larger program of planned model communities which had been begun in the early 1920's, and which were intended to point the way to a controlled pattern of decentralization for the Paris region. These model communities called garden cities or cités-jardins - took part in a long and mostly antagonistic confrontation between Paris and its emerging suburbs. Since at least the mid-nineteenth century, central Parisians had looked at the edges of the French capital with fear and distrust, as places of crime, disease, and disorder. The historian John Merriman has described these perceptions as a negative mirroring of the dominant political attitudes for which central Paris was the locus. ${ }^{2}$ By the 1920 's, this negative definition of the city's edges had been extended to include its growing suburbs, and was most graphically reflected in the efforts of the emerging planning profession. While the modernizing effects of Hausmannization were seen as having created a healthier and better-organized Paris, the suburbs were thought to be growing out of control - a chaotic sprawl with minimal infrastructure, and with tuberculosis rates often passing those of Paris.

Efforts to set-up a legal and institutional apparatus with which to plan the growth of the metropolis began just after the first World War, and were initially of only limited success. A 1919 law required all French cities with populations greater than 10,000 to produce regional plans, forcing major cities to take responsibility for organizing the land around them. ${ }^{3}$ The competition which was launched to suggest plans for the Paris region posed the problem as one of "extension" of the city, even though its actual extension of was not really an option, since most of the immediately surrounding spaces were already developed. The plan which won the 1919 competition, prepared by Léon Jaussely, conveys the limited possibilities open to planners, who could only organize transportation networks and speculate about desirable patterns of land use. Jaussely described the region as an "economic organism", and his plan reflects this biological analogy. Roads, rivers, and rail lines appear as elements in a complex circulatory system linking the heart of the capital with its hinterlands. The areas connected by this system, the flesh and muscle of the organism, were outside the control of the planner, because they were outside the authority of the central government; the periphery of the capital was already controlled by local municipalities with significant degrees both of autonomy and of antagonism towards the state.

By the time a plan was actually prepared for the Paris region, in 1934, the political dimension of the competition between urban and suburban interests apparent. Since the 1890 's towns had been allowed to elect their own mayors and municipal councils. A large number of these municipalities, dominated by industrial workers, inevitably came under the 
control of the most extreme of the parties of the left. This was, for many Parisians, yet more evidence of the threat posed by the nearby suburbs. These fears were most vividly expressed in 1927 by Edouard Blanc, who described the first ring of suburbs around Paris as a "ceinture rouge" - a "red belt" of leftist municipalities which had replaced the old ring of fortresses and defensive walls. ${ }^{4}$ Unlike these traditional defensive systems, the argument went, the new "municipal fortresses" would not look outward to help protect and define the capital, but instead turned menacingly inward toward Paris itself, toward the social and political establishment it harbored, poised for attack in the form of revolution.

In the 1934 plan, created by the architect and planner Henri Prost, the focus was again on transportation. The worrisome "red belt" suburbs were suggested only by crosshatched indicators of relative population densities emanating from the capital. Planners were in fact not so worried about density in itself, but about the chaotic ways housing was distributed within the most dense zones. Critics blamed speculative development, and especially the developers' favorite method, the lotissement. Lotissements were common forms of subdivision in which densely-grouped small parcels of raw land were sold or rented, to be built on as the buyer or tenant desired. The practice of development by lotissement was villainized, in the twenties and thirties, by planners, architects, housing reformers, and politicians of virtually every stripe. Photography combined with popular journalism to depict the horrors of the lotissement, taking advantage of its most extreme examples, such as the ring of ad-hoc dwellings springing-up outside the last, recently decommissioned wall around Paris. In fact, this most frightening of lotissements was not a "development" at all, but was instead a sort of free zone, controlled by no one, on which transient individuals and families could temporarily set up home. ${ }^{5}$

The lotissement became a symbol of the dangers of an uncontrolled and unorganized population. For planners and architects, the lotissement translated political and hygienic threats into spatial terms. The agglomerations of minimal plots of land, with no services, scattered with gardens and sheds and only provisional housing, became the negative standard by which proposals for change were judged. But laws requiring regional plans neglected to provide a legal basis or financial means for the practice of planning. Since the government was limited in its ability to take over property or control its uses, planners and housing reformers could not really take part in the comprehensive reorganization of suburban areas that they dreamed of. Faced with these limitations, their strategy was to choose specific points of engagement at which to build exemplary slices of a new suburban utopia.

These efforts were led by Henri Sellier, who ran the public housing office for the departement of the Seine - the administrative body responsible for the Paris region. Sellier was a lifelong socialist, but he was also a pragmatist, and he believed in working within existing governmental systems to accomplish his goals, chief of which was the creation of healthy and socially-meaningful environments for the working-class people he represented. Beginning in 1919, Sellier's office began buying bits of land around Paris on which to build model housing communities which he called citésjardins. Under Sellier, fifteen such communities were begun between 1920 and. At first these were closely based on the English garden-city model, theorized by Ebeneezer Howard and given an architectural and urbanistic identity by Parker and Unwin at places like Letchworth and Welwyn. Like these English garden cities, the first of Sellier's cités-jardins were characterized by groups of tidy individual or attached cottages, arranged along winding roads. By the second world war, however, as the French experiments were nearing completion, the cité-jardins ideal was gradually transformed. The model of the private house was replaced by that of densely arranged rental flats. Individually-tended gardens were replaced by a generalized green space dispersed throughout the community.

This gradual transition between two different garden-city models can be followed through the fifteen years of French inter-war garden-city activity. The Cité de la Muette at Drancy is often cited as the culmination of this transition, since it was the last of Sellier's cités-jardins to be begun, as well as the most emphatically modernist and the most dense of the communities.

But it is more than an extreme example of generalized changes. The Cité de la Muette represents a different and more profound shift than that traceable in other French citésjardins. This shift was not just one of scale, density, or image; it involved a replacement of earlier domesticallybased arguments for collective dwellings with a productionbased confrontation of the housing crisis.

The village of Drancy had been the site of one of the first garden-city experiments constructed by Sellier's office. This had been a small grouping of attached houses placed in the center of the town and laid-out in a pattern derived from the existing organization of the town: a single loop of road adjacent to a chateau and its park. As construction was underway on this first Drancy cité-jardins, Sellier was already thinking of another project in the same area, and he began in 1925 to assemble a larger parcel in essentially open land just outside the village, in a place traditionally called "La Muette."

Initial designs were made for this second Drancy citéjardins in 1933. The architects of the Cité, Eugene Beaudouin and Marcel Lods, were young graduates of the Ecole des Beaux-Arts, where Beaudouin had won the Prix de Rome in 1928. By the early thirties, influenced by Le Corbusier and by the activities of the Congres Internationaux de l'Architecture Moderne (C.I.A.M.), Beaudouin and Lods figured prominently in efforts to promote modernist design principles in France. ${ }^{6}$ The formalized planning approaches which Beaudouin had absorbed at the Ecole and in Rome, combined with the modernist preoccupation of Lods, shaped the team's early designs for the Cite de la Muette. 
Although initial assumptions were that the Cite would be formally or physically connected to the older Drancy garden city, a plan of the area prepared in 1934, as the Cité was just under construction, indicates its independence both from the earlier project and from the surrounding patterns of roads and lotissements. The housing was arranged around a series of open spaces, the most prominent of which was to be a vast green mall. While early commentators praised the common sense planning of the scheme, often assuming that the orientation was based on solar angles, Beaudouin and Lods had in fact linked the La Muette project with the other large formal presence in the area, the town's chateau. The axis running through the chateau and its gardens was continued into the main space at the Cité de la Muette. The first Drancy cité-jardins saw the existing village as an appropriate model and setting for workers' dwellings, which were carefully inserted into the town's existing form. Only half a decade later, the Cité de la Muette revealed an effort to plan in broader gestures. The scale and density at La Muette point to a coming urbanization of the Parisian suburbs, its adoption of the Drancy chateau's axis indicates a desire to formally shape suburban growth into a regional web of spaces, axes, and monuments.

The Cité de la Muette was given its monumental quality by the nature of the buildings surrounding the axial central space. On one side were a series of four-story set-back buildings, on the other a comb-like arrangement of low barres divided by formal or service courts, and connected by fifteen-story towers. The generally U-shaped arrangement was preceded by another U-shaped range of buildings turned perpendicular to the chateau axis, which passed through it. This second large space was conceived as an entry court around which would be grouped the commercial and cultural facilities for the community. Behind a colonnade at the base of apartment buildings would be found food shops, laundry facilities, day-care centers and schools.

The towers at La Muette, among the earliest residential high-rises in Europe, were added to the scheme at a relatively late stage. They contained apartments of a slightly higher standard of comfort than found in the rest of the complex, and would have allowed the project's promoters to attract tenants of greater means - either skilled workers or lower-level salaried employees. They also provided a degree of formal variety and hierarchy to the plan, and were a focus both of early attempts to promote the project, and of criticisms of it.

The dramatic quality of these spaces and forms was played-up by photographs which accompanied early publication of the project. Symmetrically composed, essentially empty, the views suggested an environment which was the antithesis of traditional urban living: clean, uncrowded, with plenty of fresh air and sunshine. From today's perspective, the photos are especially poignant. Taken during construction, and carefully set up to obscure the unfinished state of the buildings, they remind us of the eventual abandonment of the project. Only the towers and attached low-rises were fully completed, along with a piece of the set-back buildings and a much-reduced version of the U-shaped entry court, deprived of the commercial and cultural facilities which were to enliven it.

Of greater interest to the architectural press of the thirties were the technical advances employed at the Cite de la Muette. Mostly this focused on the technologies used to build the complex. The site itself was organized as a production facility, with factories for casting concrete and for fabricating metalwork, and mechanized systems of assembling these prefabricated components. The idea that the complex was an object under production was emphasized by a series of photographs of the site taken by one of the architects. Marcel Lods was a pilot and shared his generation's fascination with flight technology. Ostensibly to monitor the progress of the construction, Lods' photos were compelling advertisements for its modernity, and they always managed to include a bit of the aircraft from which they were taken. These kinds of aerial, distant depictions of the construction were accompanied by more conventional ground views of the site and the fabrication workshops it contained.

The technological content of the Cite was not limited to its production. The apartments themselves were to take advantage of advanced plumbing systems, built-in storage, central heating, and pneumatic garbage disposal chutes. Advanced as these domestic technologies were, they only took part in what was by the thirties an established tradition. Architects of social housing had for decades thought of themselves as specialists in such matters. Since the turn of the century housing design had at least partly entailed a search for ways to use new materials and methods in the interests of efficiency and healthfulness. Of most concern had always been the persistent threat of tuberculosis. In a series of studies from before the first world war, the architect Augustin Rey developed schemes for improving ventilation in buildings, including one in which food storage areas would be ventilated by fresh air drawn-in, cooled, and circulated throughout the building. ${ }^{7}$ Likewise, in the competition for housing at the Rue de Prague in Paris, of 1905, many of the entrants featured schemes for built-in systems of ventilation and waste disposal alongside their ideas for the overall layout and appearance of the buildings. ${ }^{8}$

Even in the realm of production, the application of technological research to housing construction was nothing new. What separates this earlier production research from the systems employed at Drancy is the extent to which new technologies were reflected there in the architecture itself. The method of producing the architecture was to have an uncompromising effect on its appearance, both at the level of surface and detail, and in the overall conception of the forms.

Beaudouin and Lods collaborated at La Muette, as in many of their projects, with a team of engineers and "constructors". With Eugene Mopin and Vladimir Bodiansky they developed methods for hanging the concrete cladding and floor panels onto the metal frames. Another collaborator who would eventually become better known then either Lods 
or Beaudouin was Jean Prouvé, the Nancy-based metal fabricator, inventor, and furniture designer. For the Cité de la Muette Prouvé contributed systems of window assemblies which included built-in movable screens and blinds.

The architects would later take fuller advantage of Prouvé's sheet-metal expertise in a workers' community center and market at Clichy.(1935-1939). The Clichy Maison de Peuple was clad with a metal enclosure system developed by Prouvé, and employed large-scale moving parts to adapt the building to its various functions. Most famous was a roof structure which slid on tracks in order to open the upper-level meeting hall to the sky. ${ }^{9}$ Here the image and reality of technological advancement were tied to a building type and a political program capable of fully exploiting it. By the 1930's the urban institution of the maison de peuple had acquired clearly understood socialist and democratic connotations, and had strong connections to modernist design.

In the world of housing, however, there was no obvious way to forge an alliance between existing conceptions of collective dwelling and technologically-based design. Beginning with the first debates about appropriate forms and images for workers' housing, in the 1850's, and continuing into the twentieth century, a consensus had developed around the idea that collective housing built for the popular classes should be related to traditions of apartment construction for wealthier urban dwellers. This was achieved through images of domesticity conveyed by choices of forms and materials and by the ample provision of semi-private spaces like courtyards and gardens. Despite enduring political divisions over housing policy, shared ideas about the imagery of popular housing allowed its absorption into a broad spectrum of attitudes. For the left, such housing offered a communitybased empowerment of workers along with an overall improvement in their lot. Symbolically and materially, the adoption of traditions drawn from more expensive housing indicated fairer treatment of the poor. On the other hand, those who felt threatened by urban concentrations of workers could take comfort in the notion that public housing, by mirroring traditional domestic forms, encouraged a respect for property and strengthened traditional institutions like the family. These cultural definitions of collective housing were suggested in drawings and often literally marked on the surfaces of buildings, and they emphasized the domestic role of such housing - its role as a home. This domestic imagery was further exploited in most of the cités-jardins created by Henri Sellier and his architects, and was thus extended into the suburban fringe.

With the Cité de la Muette, a quite different conception of housing can be seen emerging. Instead of domesticallybased justifications for housing, the Cité makes a claim for housing as product - engineered, manufactured, and mar- keted. This approach seemed natural in the light of the statistical gravity of the housing crisis, and considering longstanding attempts to connect architecture with engineering and industrial design. But as earlier culturally-accepted expectations about the imagery and domestic role of housing were dismantled, no replacement was proposed. The implications of new construction technologies for domestic life were explored, at least in limited ways, by the most thoughtful architects of the teens, twenties, and thirties. But no such theorization accompanied the first large-scale attempt to use such technologies, at the Cité de la Muette.

When most of the Cite was destroyed in 1976, an article in Architecture d'Aujourd'hui lamented the implications of the abandonment of this early progressive experiment. ${ }^{10}$ This was proof, according to the authors, that architecture had now been fully transformed into a disposable object of consumption. In the case of the Cité de la Muette, that transformation is seen as clearly in its design and construction as in its dismantling. In the absence of a vision of the inhabitant as a dweller in such buildings, the inhabitant's role is inevitably displaced to that of consumer.

\section{NOTES}

'Rémi Baudoui, "La cité de la Muette a Drancy (1933-1945)," Banlieue Rouge 1920-1960, ed. Annie Fourcaut. Série Mémoires, No. 18, (Paris: Autrement, 1992) 207-219.

2 John M. Merriman, The Margins of City Life: Explorations on the French Urban Frontier, 1815-1851, (New York: Oxford University Press, 1991). Merriman also explores the flipside of this phenomenon: the tendency of spatial and cultural marginality (as defined by the dominant center) to actually empower working class populations by affording freedom of organization and action.

${ }^{3}$ The loi Cornudet was passed on 14 March 1919. See JeanneMarie Dumont, Le Logement Social a Paris 1850-1930. Les Habitations a Bon Marché, Paris: Pierre Mardaga, 1991, p. 164.

${ }^{4}$ Edouard Blanc, La Ceinture Rouge, enquete sur la situation politique, morale, et sociale de la banlieue de Paris, Paris, Editions Spes, 1927, p. 9.

See also Jean-Louis Cohen and André Lortie, Des Fortifs au Périf. Paris, les Seuils de la Ville, Paris: Picard and Editions du Pavillon de l'Arsenal, 1991.

5 Francoise Dubost, "Le reve du pavillon," in Fourcaut, Banlieue Rouge, PP. 99-109.

'6eauduoin and Lods had come to Sellier's attention through their work at another ground-breaking and heavily-publicized housing development outside Paris, the Cité des Champs des Oiseaux at Bagneux.

7 Dumont, pp. 47-50, 59-66.

${ }^{8}$ See in particular the entry by Ventre and Besnard, illustrated in Dumont, p. 53.

9 Jean-Louis Cohen, "Architecture du Front Populaire," Le Mouvement Social, no. 146, Jan.-Mar. 1989, 49-59.

${ }^{10}$ Ginette Baty-Tornikian, "Obsolescence" L'Architecture d'Aujourd'hui, no. 187, Oct.-Nov. 1976, 110 